\title{
Toxic colonialism: Between sickness and sanctuary on llet la Mère, French Guiana
}

\author{
Sophie Fuggle \\ Nottingham Trent University, Nottingham \\ sophie.fuggle@ntu.ac.uk
}

\begin{abstract}
Since the establishment of slave plantations in French Guiana during the $17^{\text {th }}$ century, the small island of Ilet la Mère, located $11 \mathrm{~km}$ from Cayenne, has functioned as site of confinement, refuge, and experimentation. These roles continued during and after the creation of France's largest penal colony across the territory (1852-1953). This article identifies different phases of Ilet la Mère's colonial and postcolonial histories, and argues that the island plays an integral role in the ongoing perception and administration of French Guiana as colonial outpost and underexploited natural resource. This involves frequent misconceptions that French Guiana itself is an island, and the metonymic evocation of its islands, notably Devil's Island (one of the Salvation Islands) and Cayenne, to denote the entire territory. Such perceptions, applied from outside the territory, alongside local engagement with lesser-known islands like Ilet la Mère, contribute to the creation of a 'toxic island ecology'. Toxicity, defined as more than contagion and contamination, incorporates other practices and discourses which work to draw attention away from environmental and human rights abuses taking place on the mainland. The article concludes with reflection on the island's current usage as a nature sanctuary where visitors can interact with overly tame squirrel monkeys.
\end{abstract}

Keywords: French Guiana, Ilet la Mère, penal colony, yellow fever, Pasteur Institute, toxicity, toxic island ecology

https://doi.org/10.24043/isj.184 • Received April 2021, Early access October 2021

(C) Island Studies Journal, 2022

\section{Introduction}

With the signing of the Paris Treaty of 1814, France affirmed its colonial occupation of the South American territory of French Guiana. This followed a series of largely calamitous attempts at colonisation by various European powers (Mam-Lam-Fouck, 1982). Since the late $18^{\text {th }}$ century, the small island of Ilet la Mère has functioned as leper colony, penal settlement, prison farm, and disease laboratory. Located approximately $11 \mathrm{~km}$ from the territory's largest town and administrative centre, Cayenne, the island's settlements have been abandoned on more than one occasion due to insalubrity and disease outbreaks. Today, the site operates as a nature reserve. Despite all these roles, Ilet la Mère is often omitted from general histories of the penal colony - and where it is mentioned by scholars, it is often just 
a footnote. In this article, I take up its story in order to explore the different forms of toxic island ecology located throughout its colonial and postcolonial histories. The concept of 'toxic island ecology' is developed with reference to existing scholarship on island ecologies and postcolonial environmental criticism. The aim is to contribute to ongoing discussions and debates concerning how islands of varying size are co-opted in order to obscure toxic colonial and postcolonial practices elsewhere. Notably, Clarke and Johnston (2016) have identified three tropes - penitentiary, laboratory, and sanctuary - applied to Tasmania since the first convict settlements in 1803. Their consideration of the smaller islands, such as Bruny Island, located off the coast of Tasmania emphasizes the use of such extra-peripheral spaces within the penal colony for quarantine and other forms of sequestration, as was also the case with the islands located off French Guiana.

An interdisciplinary approach is taken in presenting Ilet la Mère and analysing its complex histories. This mixed method approach includes close textual analysis of archival documentation housed in the Archives Nationales d'Outre Mer in Aix-en-Provence and draws on ethnographic fieldwork conducted in French Guiana (2017-2019). Fieldwork data collected included photographic documentation, first-person observations, and informal interviews with other visitors. The article's theoretical framework adopts and develops concepts found in postcolonial ecocriticism, island studies, and heritage studies. It is also indebted to existing historical scholarship conducted on French Guiana, in particular its operation as a penal colony (Pierre, 2017; Sanchez, 2018). The research presented here is positioned within a longer-standing interest in 'carceral cultures' and, notably, the question of what happens to spaces of incarceration after they cease to detain and imprison. Fieldwork conducted in French Guiana was informed by earlier visits to other former sites of confinement in the United Kingdom, Turkey, Australia, and Japan. The opportunity to visit these sites attests to my privilege as a citizen and full-time academic researcher from the Global North, as do the related opportunities to undertake archival research in France, New Caledonia, and French Guiana. Although my personal experience of prison and the criminal justice system is purely academic, my interest in defunct prisons is linked to an abolitionist perspective. As such, my work is aimed at exploring how all prisons might become 'ruins of the future', as well as how museums and heritage sites often work to affirm rather than critique the role of the prison in contemporary society. Having visited spaces of ruination, including Ilet la Mère, my position vis-à-vis the potential of ruins to help us imagine an end to incarceration has become more nuanced, and is also indebted to the work of Stoler (2016) on the problematic function of colonial ruins.

Following this introduction, the article will first situate Ilet la Mère in relation to the wider geography of French Guiana, considering in particular the importance of the territory's islands in popular representations of the territory. The second section will briefly set up the concept of toxic colonialism as it might be applied to French Guiana's history as a penal colony and beyond. The term 'toxic' will be considered in relation to other discourses of 'disease' and 'contagion' as well as the notion of 'toxic heritage'. In the third section, the specific history of Ilet la Mère as a leper colony and site for sick convicts is explored. The theme of toxicity is developed further in section four, which looks at the harvesting of ricin which took place on the island in the 1860s. Ricin has both therapeutic and toxic potential, thus functioning as both material example and metaphor of the island's paradoxical status. The fifth section considers the island's use as a prison farm in the 1920s and subsequent use 
by the Institut Pasteur in the 1980s and 1990s, together with its current role as nature sanctuary. These three stages in the history of the island are linked by ideas of experiment and ecology, marking the continuity of colonial discourses within and towards French Guiana following departmentalisation in 1946. To conclude, the reader is taken to Ilet la Mère, where an encounter with squirrel monkeys offers final pause for reflection. Unless otherwise stated, all translations from French are my own.

\section{Legible geographies: Locating French Guiana}

In the introduction to Locating Guyane, Wood and MacLeod (2018) propose the repositioning of French Guiana from the periphery to the centre of contemporary French and Francophone studies. Not only is French Guiana the largest of France's departments, but it is also a site where some of the most significant ecological and geopolitical stakes play out. Following the closure of the Hammaguir rocket launch site in Algeria in 1966, the territory has housed the Centre Spatial Guyanais, operated by the European Space Agency and France's Centre National d'Études Spatiales. Arguably, French Guiana has also been overlooked by the field of island studies as a site which continues to be perceived from without in terms of oversimplified representations of islandness. These are largely conceived in terms of its earlier function of exile and confinement, and as a virgin, uninhabited territory rich in natural resources awaiting exploitation. Such perceptions, which persist in French media, are all the more significant given that French Guiana is not actually an island.

This misattributed island status can be better understood with reference to Grydehøj's (2018) notion of "legible geographies." In a sense, the entire territory of French Guiana operates as a kind of mirror image to Grydehøj's (2018) example of Kalaallit Nunaat (Greenland). Where Kalaallit Nunaat, due to its size, is only visibly an island when viewed by satellite imagery, French Guiana is often mistaken for an island despite not being one. Prior to his election as President of the French Republic, and in response to the ongoing social movements taking place in French Guiana at the time, Emmanuel Macron referred to the territory as "une ile" (an island) (LePoint.fr, 2017). Even those who are fully aware of its nonisland status find it hard to resist applying island imagery to the territory.

Mistaking French Guiana for an island is in part due to the large rivers which establish its borders with Brazil and Suriname. The interior, which forms part of the Amazon rainforest, remains largely undeveloped in terms of transport infrastructure, meaning that access to most of the territory is limited to boats and small aircraft. A second and more telling reason for this confusion occurs as a result of the prominence given to the various small islands located off its coastline and on its rivers in the territory's historical and literary presentation (see Figure 1). Notably, these small islands played a key role during the territory's operation as France's largest overseas penal colony (1852-1953), resulting in the use of two dominant metonyms adopted by those from outside. It is useful to consider these metonyms before focusing on Ilet la Mère. In the French lexicon, the territory as penal colony continues to be referred to as "Cayenne." Cayenne is French Guiana's largest town and is located at the tip of what was once known as Ile de Cayenne, since it is separated from the mainland by the Mahury estuary and the Cayenne and Tour de l'Ile rivers. This direct association of Cayenne with the penal colony occurs despite the fact that it was an established town well before the arrival of the penal colony in 1852. Moreover, 1863 saw the creation of the town of Saint Laurent du 
Maroni some $250 \mathrm{~km}$ from Cayenne as the purpose-built administrative centre of the penal colony.

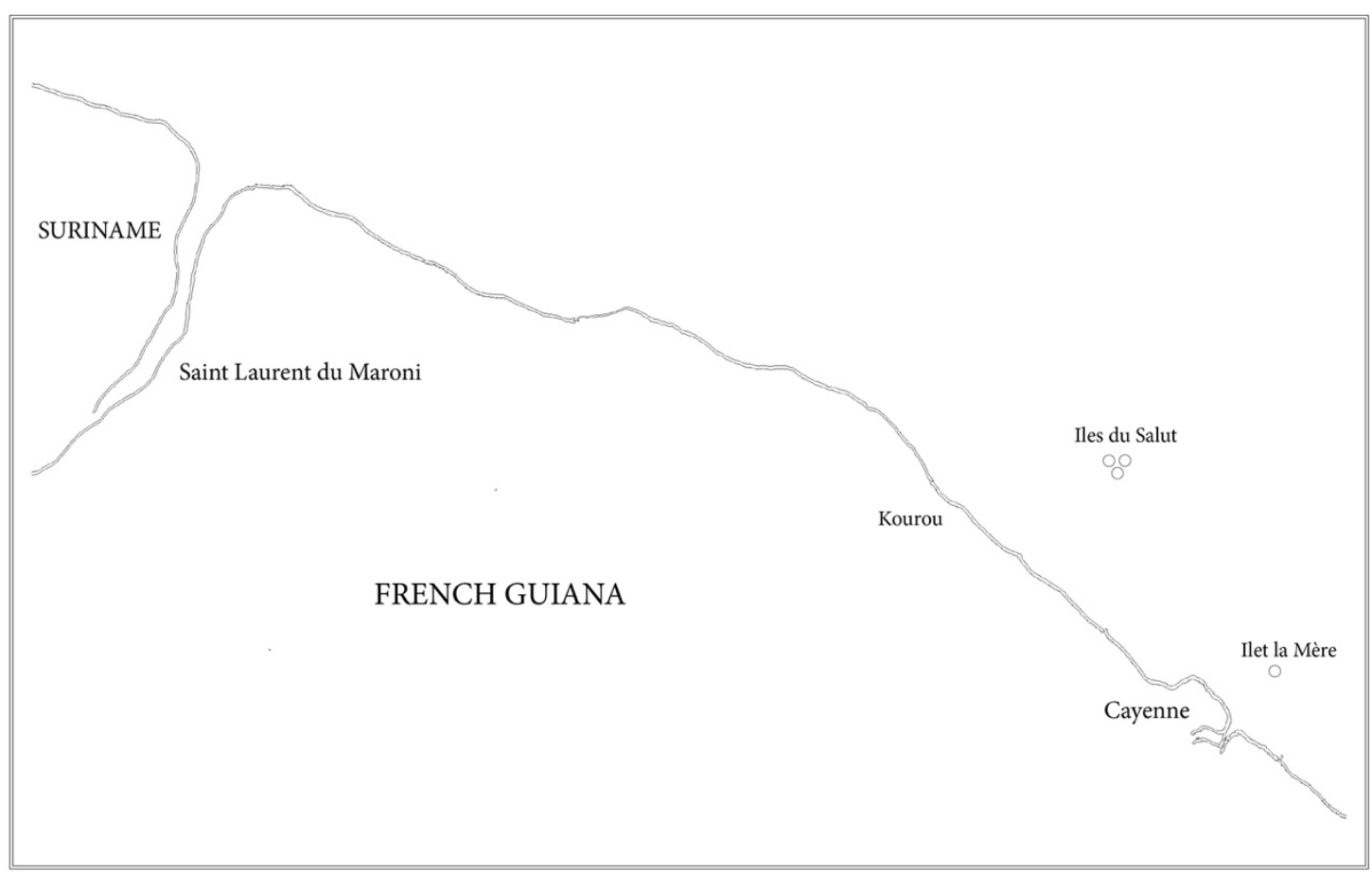

Figure 1. Simplified map of French Guiana's coastline indicating approximate location of Ilet la Mère and the Iles du Salut (Salvation Islands) in relation to Cayenne. Source: S. Fuggle.

In Anglo-American cultural constructions, it is not Cayenne but Devil's Island (Ile $d u$ Diable) that functions as metonym for the entire penal colony. This is even more of an imaginative leap given that Devil's Island is approximately $0.14 \mathrm{~km}^{2}$ in size and only ever held a tiny handful of convicts out of the 70,000 sent to French Guiana. Those imprisoned on Devil's Island were generally political deportees, including, most notably, Alfred Dreyfus during his exile between 1895 and 1899. Devil's Island belongs to a small collection of islands known as the Iles du Salut, or Salvation Islands, which also include Ile Royale and Ile Saint Joseph. Today, these islands are a popular day trip destination by catamaran, during which it is possible to visit vestiges of the former penal colony. On the largest island, Ile Royale, some of the former administrative buildings have been renovated and converted into accommodation, and it is possible to stay on the island overnight.

Ilet la Mère, which can be translated literally as "Mother Island," belongs to a scattered group of islands known as the Iles de Rémire, which are largely absent from popular representations and histories of French Guiana. The islands are more widely scattered than the Salvation Islands, with Ilet la Mère located about $11 \mathrm{~km}$ from the territory's main seaport, the Degrad de Cannes, in Rémire-Montjoly, a suburb situated to the southeast of Cayenne. La Mère is the largest of the islands, with a surface area of approximately $1.296 \mathrm{~km}^{2}$. The other islands in the archipelago are named Ilet le Père (the Father), Les Deux Filles (the two daughters) also known as Les Mamelles (the breasts), Le Malingre (the frail or puny one), and the Enfant Perdu (lost child). These appellations date from at least the $18^{\text {th }}$ century and are explained by an origin story recited on boat tours to Ilet la Mère (see also Calmot, 1979). 
According to legend, a family of giants got pushed out to sea and were separated during a storm. The parents, trapped in the silt that surrounds Cayenne, managed to locate their two daughters nearby but sent their servant, le Malingre, in search of the smallest child. The Malingre got stuck, but eventually found the child at the mouth of the Mahury River. Trapped in place for thousands of years, the giants ossified, forming the group of islands. Ilet la Mère is the only island in the group that is accessible to the public today. Small motorboat tours bring visitors for half- and full-day tours. Unlike Ile Royale, there are no amenities on the island, and overnight stays are prohibited.

The origin story is worth noting due to its emphasis on deep, geological time. This contrasts with the story recounted to explain the appellation of 'salvation' which was applied to the Iles du Salut relatively recently. Ile Royale, Ile Saint Joseph, and Ile du Diable were once known collectively as Les Iles du Diable due to their rocky terrain and the dangerous crosscurrents which made docking hazardous. In the 1760s, however, the islands became a site of refuge; 1400 colonists were sent there from Kourou, which at that point was an unfinished town whose unsanitary conditions were exacerbated by flooding during rainy season (Lowenthal, 1952, p. 29). Thus, where the islands had once been considered hostile, they were reimagined by the colonial authorities in terms of the 'salvation' they offered in contrast to the disease-ridden Kourou. This notion of 'salvation' was carried over into the early years of the penal colony, during which transportation was presented as a chance at redemption for convicts and the colony alike.

In comparing these two 'naming' stories, one focused on mythical origins and the other on recent colonial history, it is possible to identify the different ideological functions of the two sets of islands today. The notion of 'salvation' was subsequently applied to the role of the Iles du Salut as part of the penal colony. Today, the name emphasizes the archipelago's recent colonial history, allowing this history to be annexed from the mainland. The Iles du Salut (now under the jurisdiction of the Centre National des Études Spatiales) provide an exceptional space in which vestiges belonging to the penal colony have been preserved and restored. Such conservation has, arguably, endorsed the general erasure of the problematic memory of the penal colony from Kourou, Cayenne, and their environs. In Cayenne, the population was keen to get rid of the negative associations of the territory with the penal colony. Memorials have focused instead on sites associated with slavery and its abolition. In Kourou, large-scale social cleansing took place from the mid-1960s onwards in order to make way for the Space Station and its supporting infrastructure and housing.

Conversely, on Ilet la Mère, the absence of significant ruins which tell the story of the island's multiple histories allows for its presentation as a site celebrating the 'return' of nature. Focusing on other sites across French Guiana, Spieler (2012) has commented on this abandonment and re-wilding as a specific form of colonial legacy. In particular, she puts forward the idea "that everything including primary forest, secondary forest, and abandoned lots on the edge of Cayenne should count as elements of a manmade world and not of a world that man failed to constitute" (Spieler, 2012, p. 4). These conclusions are affirmed by a report produced following archaeological research on the island undertaken since 2010. According to the report, "the image which emerges from this initial archaeological study of Ilet la Mère is one of a space entirely anthropized, a process which probably started with the arrival of the first colonists and then accelerated during the $19^{\text {th }}$ century" (Payraud, 2015, p. 205). 
Some sites are rendered inaccessible by the processes of abandonment and re-wilding that Spieler (2012) redefines as evidence of colonial intervention. However, contemporary presentations of the territory's islands, including Ilet la Mère, might instead be defined in terms of what Harrison (2020) has called "heritage as future-making practice." Here, the notion of 'heritage' continues to imply ideas of property and ownership associated with earlier forms of wealth and inheritance. French Guiana's natural heritage continues to be highlighted in French political discourse as a rich resource for exploitation. At the same time, notions of stewardship and ecological responsibility are evoked in response to contemporary social problems, and in order to disavow the needs of multiple populations living across the territory. Ilet la Mère offers a small-scale vision of a territory in which nature is not only permitted to return and proliferate but, in doing so, mitigates the damage (human and ecological) of previous human activity. Consequently, it hints at a future built around such "landscapes of exclusion" (O'Brien, 2015) maintained and sustained through the development of a viable ecotourism industry. As I shall explore later in the article, such a vision persists despite longterm failures to develop tourism across the territory and, moreover, functions as a distraction from other more toxic interests, notably invasive resource extraction.

\section{Toxic colonialism}

In the mid $-19^{\text {th }}$ century, French Guiana was presented as a place offering hope of rehabilitation for France's growing convict population (Pommeuse, 1832, cited in Toth, 2006, p. 5). Such hope rapidly gave way to a more sustained image as a repository for these unwanted citizens of France and its colonies, associated with disease and the diseased. The colony and its convict population were frequently described in terms of "gangrène" (Tripot, 1910, p. 5), an infected limb of the French Empire to be cut off. Such metaphors of disease and social hygiene were coupled with the challenges of actual diseases and poor sanitation and nutrition within the penal settlements established in French Guiana, where in 1856 the mortality rate was $26 \%$ (Pierre, 2006).

Much work has been done recently on the use of metaphors of both contagion and disease. DeLoughrey (2019, p. 23) has pointed out how discussions or theories of the Anthropocene which focus on the loss of populations through epidemics and pandemics often obscure the violence and inequality underpinning the impact of contagion upon different populations. At the same, time she points out ways in which epidemics are further conflated with histories of forced migration and war in ways which essentialise genocide as part of human nature. Raza Kolb (2020) also looks at how language of contagion and disease has been used against specific groups, particularly Muslims, as a deliberate colonial and neoimperial tactic. In this context, it is worth noting that the period that forms a key focus of this article, the late $19^{\text {th }}$ century, saw convict transportation to French Guiana limited to colonial subjects from North Africa (Pierre, 2017). Where French Guiana was presented as a solution to the 'disease' of crime in mainland France, the actual diseases ravaging the convict population meant that, for a period of approximately twenty years, the territory was only deemed fit for colonial subjects. From 1887 until 1897, European convicts were sent exclusively to New Caledonia. The paradoxical logic was that those from tropical or subtropical climates would be better acclimatised and more likely to possess some natural immunity to diseases such as malaria and yellow fever. On the other hand, these were bodies 
considered more expendable with their mortality rates subject to less public scrutiny back in France. Throughout the hundred-year operation of the penal colony, different races and nationalities within the convict population (as well as the guards) were played off against one another, affirming the violent hierarchies and divisions of the system. North African convicts were often given the role of 'porte-clés' (lackeys) and, as such, enjoyed certain privileges over other convicts, thus engendering resentment and distrust. With the creation of three new camps for Vietnamese convicts in 1931, a group of Senegalese Tiralleurs were brought in to guard them.

In adopting the term 'toxic' to describe the appropriation of island ecologies in French Guiana, it is important to acknowledge how it functions, along with 'contagion' and 'disease', as a heavily loaded metaphor. Recently, it has been used to describe behaviours that were once ignored or encouraged but are now recognised for the long-term harm that they cause; 'toxic masculinity' is a well-known example of this. What is interesting in this use of 'toxic' is the emphasis on "slow violence" (Nixon, 2011) caused by something not acknowledged or diagnosed as such, often considered harmless and even, on occasion, therapeutic or beneficial. Considering the current metaphorical role of the term 'toxic' to signal certain behaviours within socio-cultural settings such as the workplace, how might we map these back onto other less-considered spaces? How might we think more carefully about how practices and activities that are presented as being minimally harmful or even beneficial are often modes of maintaining structural inequalities, reappropriating resources, and deferring responsibility for long-term social and ecological harm?

Here, we might draw upon the concept of "toxic heritage" proposed by Wollentz and Högberg (2020). The term deliberately conflates two potential meanings of 'toxic': the question of managing nuclear waste as the embodiment of toxic waste produced by human activity, and the potential for different forms of heritage practice to endanger contemporary social cohesion. In particular, Wollentz and Högberg (2020, p. 295) identify the practice of "containment" that occurs at both types of site. This resonates with the function of islands in French Guiana as sites in which difficult histories can be 'contained' and carefully managed but also, as is the case with Ilet la Mère, in the presentation of islands as sites of protected biodiversity and privileged spaces of 'ecotourism'. In order to consider this idea of 'containment' as it pertains to Ilet la Mère today, it is useful to situate contemporary practices in the context of the island's historical uses as a site of both containment and convalescence.

\section{Worthless remains}

The island's role as a space of exile and confinement predates the establishment of the penal colony during the mid $-19^{\text {th }}$ century. From the $17^{\text {th }}$ century onwards, the three largest islands belonging to the Iles de Remire were inhabited by Jesuits (Calmot, 1979). On 9 January 1777, an ordonnance announced the creation of a leper colony on Ilet la Mère (cited in Fougère, 2018, p. 38). By 1818, the island housed between 40 and 80 'invalids'. This was during the period prior to the abolition of slavery in 1848 and the establishment of convict transportation to French Guiana in 1852. In this context, it is important to note that it was only mixed race and Black men, both free and enslaved, who were sent to the island. White Europeans diagnosed with leprosy were given the option to return to Europe. 
As Fougère (2018, p. 60) argues, there was no real reason Ilet la Mère could not have provided a sustainable, humanitarian space for those afflicted with leprosy. However, life on the island qua leper colony was defined by the same economic exploitation that prevented slave owners from reporting cases of leprosy amongst their labour force. This meant that any potential for self-sufficiency was circumvented by poor management which sought to profit from the island's produce. Similarly, the possibility of creating a therapeutic space for the worst-afflicted was limited due to restricted medical visits and cramped living conditions. In 1823, the island was abandoned, with its population transferred to Ile Royale.

When the penal colony (commonly referred to as the bagne) was established in 1852 following the abolition of slavery, it was perhaps logical that Ilet la Mère was adopted as one of the original camps along with the Salvation Islands. The neighbouring island of Ilet le Père was also proposed as a site for female convicts, although this never materialised and the small female convict population was ultimately settled in Saint Laurent du Maroni (Godfroy, 2002, p. 61). In the early years of the penal colony, the hope was to succeed in developing the colony where the slave plantations had largely failed, which included taking over sites that had been former plantations.

Following the inauguration of the penal colony, Ilet la Mère was used for political deportees who were exempt from forced labour (Calmot, 1979). However, after a revolt in 1853 , stricter regulations were enforced in terms of both work and rations. In 1854, fifty out of 180 prisoners located on the island died due to the harsher conditions. As the organisation of the penal colony developed and evolved, so did the role of Ilet la Mère. Sanchez (2019) points out that both the Iles du Salut and Ilet la Mère offered limited space and infrastructure for the arrival of new convoys of convicts, which led to the creation of Saint Laurent du Maroni as purpose-built prison town in 1862. Thus, during the 1860s, Ilet la Mère was used to house between 150 and 300 convicts who, due to old age or infirmity, were unable to carry out more than light work. Those who were not sick enough to be in hospital but who required a period of additional convalescence were also sent to the island before returning to the work camps elsewhere in the colony. In his memoir recounting a visit to French Guiana in the early 1860s, Frédéric Bouyer (1867, p. 139) describes the island as "l'hôtel des invalides du bagne."

During this period, three different governors assumed oversight of the colony. Inspection reports sent from French Guiana to the Minister of the Colonies in Paris show their different attitudes towards Ilet la Mère as a site of sanctuary. In October 1863, Governor Louis-Marie-François Tardy de Montravel (1863a) writes to the Minister of the Colonies that:

Ilet la Mère continues to provide me with the same spectacle of elderly and infirm undertaking with great difficulty the necessary work required to maintain the penitentiary in good condition and according to its needs. It was chosen due to its salubrity as a place of refuge for this class, Caput Mortuum of transportation and as an overflow [exutoire] for the overcrowded hospital in Cayenne.

The Latin term Caput mortuum can be translated as "dead head" or "worthless remains," and was associated with early- $17^{\text {th }}$-century alchemy, referring to the "worthless residue left over after an experiment" (Eastaugh, 2004, p. 81). It was also used to denote "the last element of all bodies that can no further be altered by any art whatsoever" (Sullivan, 1794, cited in 
Eastaugh, 2004 , p. 81). The term was also adopted around the $18^{\text {th }}$ century to refer to a reddish-brown pigment and, thus, also visually evokes the convicts' weather-beaten skin, attesting to decades working under the tropical sun. The subsequent reference to this group of men as constituting "an overflow" of the overcrowded hospital offers a supplementary image of waste, decay, or sewage that requires management and containment. A later report from December of the same year describes the site (together with the Montagne d'Argent camp) as "triste" (sad) and repeats the claim that it represents the Caput Mortuum of the penitentiary (Tardy de Montravel, 1863b). Taking over as Governor in 1864, Antoine Favre assumes a similar perspective towards the island, describing it in a report from April 1865 as "a depot of the elderly and frail, those maimed in every possible way, blind, lame and amputees etc."

It is only with the arrival of Governor Hennique in 1866 that the island is represented in the inspection reports as more than a repository in which the terminally ill are dumped, having nothing left to offer the colony. Hennique's reports express a desire to both mitigate and justify the elevated costs of managing the island. The penitentiary on Ilet la Mère is described as providing a necessary service in relieving pressure on hospitals in both Cayenne and Saint Laurent du Maroni. In April 1868, the Governor insists that the only building costs now incurred are basic maintenance. Most 'invalids' are not hospitalised and so, beyond their alimentation, cost little to the administration. A diet based on vegetables grown on the island is highlighted as contributing to excellent sanitary conditions (Hennique, 1868).

\section{Harvesting ricin}

An inspection made by Hennique, dated 30 October 1866, notes the serendipitous circumstances ("un heureux concours de circonstances") which mean that those undergoing medical and therapeutic treatment on the island are able to apply themselves to the (comparatively) light work of harvesting ricin. The production of oil from seeds extracted from the Ricinus communis plant, generally known in English as castor oil, supplied the hospitals in Cayenne. Ricin is a significant and, indeed, symbolic choice of agricultural product for a site housing those rendered terminally ill and infirm as a result of conditions in the penal colony. Castor oil has been used for centuries to treat a wide range of ailments. The plant is thought to have originated in Africa, and was extensively cultivated in Algeria under French colonial occupation ("Castor Oil," 1857). It was also used to treat symptoms associated with outbreaks of typhus in France's dockyard prisons (bagnes portuaires) which preceded overseas transportation (Faure, 1846, p. 4). In the penal colony, castor oil was likely to have been used by doctors as an anti-inflammatory and to treat sores and fungal infections. It would have also been employed as a laxative (purgatif), a role which emphasizes the punitive as much as the therapeutic employment of castor oil (Leong-Salobir, 2011, p. 66).

In its unprocessed form, the castor bean is particularly toxic. Ingesting seeds can kill both humans and animals, and there is currently no effective antidote (Centers for Disease Control and Prevention, 2018). Ricin, the toxin contained in the castor bean, is estimated to be 6,000 times more poisonous than cyanide (Raver, 1994). It is known for its potential use as biological weapon (Archer \& Bawdon, 2010) and was already being considered for this purpose by the U.S. War Department in 1918 (Cope et al., 1946, cited in Audi et al., 2005, p. 2342). Today, ricin is widely banned as a substance and the production of castor oil is 
undertaken with extreme care. It is unclear what measures were taken to ensure convicts on Ilet la Mère limited their exposure to the toxic effects of the beans. However, it is clear that they quickly became aware of these. There are multiple accounts which describe how convicts would place a grain of ricin in their tear ducts in order to produce the same effects as conjunctivitis (Rousseau, 1930; Sanchez, 2019). Since conjunctivitis is both highly infectious and, when untreated, can result in loss of sight, convicts displaying symptoms would be transferred to the hospital thus escaping their work detail or, for those detained on the islands, cellular confinement. While these accounts postdate the harvesting of ricin on Ilet La Mère, they nevertheless offer insight into the complex ways in which convicts negotiated the toxicity of their existence and environment. Survival and respite from the brutal conditions of the forest camps required instrumentalising or at least simulating the most toxic effects of forced labour and unsanitary living conditions.

The overall image presented in Governor Hennique's reports from the late 1860s is of an island retreat where those too ill to survive elsewhere in the colony find meaningful existence via the cultivation of ricin which, in turn, stocks the hospital in Cayenne. This is an image that differs both from the earlier reports depicting Ilet la Mère as a dumping ground and the sensationalist accounts offered in Bouyer's memoir of assassinations and escape attempts. The framing of life on the island as a site at once therapeutic and sustainable is nevertheless underpinned by the toxic potential of ricin. Despite accounts of agency and resistance, the enduring image of the bagne is one which reduces convict lives to a form of matter that is not simply surplus but, due to sickness, disease, and abject poverty, threatens to 'contaminate' the rest of the colony. Ilet la Mère thus becomes a site of containment for a human version of what Wollentz and Högberg (2020) have termed "toxic heritage." As we shall see, later uses of the island reverse this spatial arrangement in relation to ongoing toxic practices on the mainland.

\section{Illusions of sustainability and sanctuary}

Due to an outbreak of yellow fever, Ilet la Mère was again abandoned in 1875. Its closure followed those of a number of other camps in the region due to similar outbreaks (Pierre, 2017, pp. 106-107). From 1910 onwards, Les Hattes (now part of the Awala-Yalimapo commune), located on the northern coast on the border with Suriname, became the main centre for those too ill or old to work in the forest camps. In his memoir produced following time stationed in French Guiana between 1920 and 1922, the doctor Louis Rousseau (1930) identifies the problem of 'doublage' as extending beyond the earlier image of 'worthless remains' produced by the penal colony. The system of doublage required all convicts spend the equivalent of their sentence as a free citizen (libéré) in French Guiana before being permitted to return to France. Those with sentences of over eight years were obliged to remain in French Guiana for life. The rationale was that former convicts would be granted small concessions and, thus, contribute to the development of the territory. However, the system was one of the biggest failures and cruellest aspects of the penal colony. Released convicts were rarely given workable concessions and struggled to secure paid labour due to the territory's large supply of free labour provided by the convict population. Moreover, not only do those released into the colony require financial support and medical care but, due to their weakened immune systems, are presented by Rousseau as carriers of diseases from the 
penitentiaries and camps into the villages and communes where they are relocated. For Rousseau (1930, p. 121), this constitutes the biggest case for the abolition of transportation, which he condemns as "a monstruous error of hygiene."

Like a number of other former camps located around Cayenne (including Montagne d'Argent) which were closed down due to poor hygiene and outbreaks of disease, Ilet la Mère was left to ruination (Pierre, 2017, p. 144). After decades of abandon, in 1923 the island was rented from the penal administration by a former convict, Edmond Duez. Duez had been sentenced to transportation in 1911 for fraud, and embarked for French Guiana on 2 August 1912 (Administration Pénitentiaire, 1911-1924). He spent his entire 12-year sentence on the Iles du Salut, where he was employed as an accountant. His experience of the bagne was thus largely limited to that of island dwelling. His administrative role also meant that his experience was very different from that of convicts sent to the islands for escape attempts and other infractions; while most convicts slept in barracks or cells, he had his own private lodgings. Following the completion of his sentence, Duez was required to remain in French Guiana under the doublage law. His story is perhaps one of a very few examples where doublage resulted in a positive outcome.

As indicated above, for most convicts, doublage was worse than their original sentence since they were no longer fed and housed by the penal administration. Given the abundance of free labour offered by the penal colony, no one wanted to pay a living wage to freed convicts and they were left dependent on charity. Moreover, years of poor nutrition and hard labour had left many of them with long-term medical conditions, as evidenced in the reports from Ilet la Mère and Louis Rousseau's conclusion that convict transportation constituted a 'monstruous' mistake in terms of hygiene. Duez's story is different. On completing his sentence, his wife joined him in Cayenne and they hired about 20 convicts to clear the overgrown vegetation on Ilet la Mère before setting up a small prison farm selling products at the market in Cayenne (Calmot, 1979). An account by reporter Louis Roubaud for the magazine Détective following a visit to Duez and his wife on the island in 1929 declared the farm a notable success (Larique, 1929).

The exceptionality of Duez as model convict is framed by his concession on Ilet la Mère. Where his story differs from other narratives picked up by the generally sensationalist and scandal-seeking Détective, interest in Duez nevertheless lies in the specificity of his character and the relative success of his time spent in French Guiana. Within Roubaud's narrative, Ilet la Mère becomes the obvious location for Duez to "take refuge" (se réfugier; Larique, 1929) away from the human and geographical vicissitudes of the mainland. In contrast to the island's earlier use as repository for unwanted elderly and infirm convicts, it is now reimagined as a site of exceptional achievement. The prison farm offers evidence that the logic of the penal colony could work - but only, perhaps, in the case of those convicts who should never have been sent to French Guiana in the first place.

The image of a model farm seems to embody the original utopian visions of the penal colony, which was presented as a site which would, similar to Australia, give men a second chance via working the land and producing sustainable crops and existence (Forster, 1996). This vision was short-lived in French Guiana, and Duez's reactivation of it 70 years later seems to occur alongside a more repressive functioning of the penal colony rather than from within it. It also echoes other examples of short-lived sustainability found elsewhere in the colony. Notable here is the case of Mana, where catholic missionary Anne-Marie Javouhey 
established a successful agricultural colony with over 500 freed West African slaves during the 1830s (Curtis, 2008, p. 22). As Curtis (2008, p. 23) suggests, such a project was only possible at a site on the periphery of the already peripheral space of French Guiana. Moreover, Cornuel (2003, p. 219) points out that, with the abolition of slavery in 1848 , the project at Mana was aborted by the colonial administration in favour of the penal colony. Thus, a successful example of collective endeavour and sustainable farming was replaced by the violent individualism required to survive life in the bagne (Cornuel, 2003, p. 218). Cornuel (2003, p. 219) suggests that the irony of this transformation is particularly cruel given the forest camp closest to Mana was Charvein, notorious for its brutal conditions and mortality rates. What all these examples demonstrate collectively is the persistent image of the territory as a site of experimentation. Moreover, the history of colonialism and its aftermaths has largely been defined in terms of failed projects or experiments. Within this discourse, successful or sustainable projects are short-circuited or abandoned.

Duez died about ten years after his release, and his wife returned to France (Calmot, 1979). Ilet la Mère was abandoned once more. In the early 1980s, the island was taken over by the Pasteur Institute in Cayenne as part of their ongoing research on malaria. Thus, the island became the site of new forms of experimentation. Squirrel monkeys were brought from the mainland to be used in testing, with the hope of producing a new serum with which to treat malaria. Some monkeys were left to roam free, while others were kept in cages. With the advent of stricter regulations against the use of animal testing in medical research, the Institute ceased their work on the island in 2001, leaving the majority of the monkeys to their freedom (Institut Pasteur de la Guyane, 2015).



Figure 2. Vestiges of settlements and a fromager tree on Ilet la Mère. Photograph by S. Fuggle.

Today, Ilet la Mère is presented to tourists and residents as a miniature wildlife sanctuary. Although the island lacks the biodiversity of inland Amazonian sites due to repeated human 
occupations, it nevertheless hosts over 40 species of birds and a number of small mammals, such as agoutis, in addition to the large population of squirrel monkeys (Conservatoire de l'espace littoral, 2014). On the short boat journey that visitors can take to the island, the captain points out Ilet le Père, informing passengers that the island is home to the Ibis Rouge, once over-hunted due to the desire for its red feathers in Paris fashions. Very little built heritage remains on Ilet la Mère, although the paths once used by convicts have been cleared to provide walking trails (see Figure 2). Non-descript piles of bricks and stones can barely be made out amongst the large fromagers known for their huge protruding roots. Everything has been dismantled. This differs significantly from the restored architecture on Ile Royale and the stabilised ruins on Ile Saint Joseph, both of which provide a stark reminder of their penal histories. A panel at the entrance to the trails indicates Ilet la Mère's multiple human presences. It is possible to follow a path around the island's perimeter which takes visitors to a small beach as well as to the island's highest point. The island's interior is largely inaccessible due to dense secondary forest. On talking with other visitors during a site visit made in June 2017, it became apparent that the attraction of Ilet la Mère lies in the absence of built heritage. Instead, it is a site given over to nature, in contrast to other sites in French Guiana. Yet, informal conversations with heritage professionals also identify the site as a missed opportunity, particularly given that the built heritage of the penal colony has largely been effaced from Cayenne, in contrast to the Salvation Islands and Saint Laurent du Maroni.

As Agius et al. (2019) argue in relation to the Mediterranean, smaller islands are often preferred ecotourism destinations due to their being less urbanised or possessing other potentially conflicting functions. That said, the study by Agius and colleagues (2019) focuses on ecotourism as a positive, sustainable practice and does not actively challenge the myth of the 'pristine', untouched, or re-wilded island. The claims made about Ilet la Mère in municipal and tourist office material (Conservatoire de l'espace littoral, 2014) are fairly limited and do not embody the types of "conspicuous sustainability" highlighted by Grydehøj and Kelman (2017). Nevertheless, the site provides a focal point, particularly for local residents, which emphasizes the space in terms of its re-wilding. In this respect, Ilet la Mère draws focus away from deep-rooted social inequalities and widespread environmental problems found on the mainland.

Such inequalities result from the elevated cost of living produced by an ongoing reliance on French imports, limited professional employment opportunities for local populations (Temporal et al., 2011), and repressive forms of border control imported from Fortress Europe (Benoit, 2016). Where the ecological impact of the Space Station operations has global reach not least in the creation of "space waste" (Stansbery, 2011), specific local, tangible environmental concerns include the extensive use of pesticides ("Ce pesticide interdit," 2015; Jantet et al., 2012) along with the controversial gold-mining activity. A number of recent studies have emphasized the ongoing impact of mercury contamination of French Guiana's rivers as a result of small-scale practices (Goix et al., 2019; Hellal et al., 2020). The controversial Montagne d'Or open-pit goldmine project, which would use cyanide rather than mercury ("“There is no ban on the use of cyanide for gold mining...,", 2018), was suspended in 2019 following local and international concern about its ecological impact. However, at the time of writing (Spring 2021), it appears rulings against the project are being overturned, with mining companies such as Orea involved in ongoing preparations for future extraction (Casey, 2021; Le Figaro \& AFP, 2020). 
Since the 1970s, tourism has been presented as a major development opportunity for the territory. During the 1980s, then-mayor of Saint Laurent, Léon Bertrand, proposed creating a Club Med resort on the site of the town's former Transportation Camp (Maurice, n.d.). However, such development has never materialised. Today, a lack of public transport and elevated operating costs mean that the limited number of tourist destinations across the territory remain reserved for middle-class creoles and white metropolitans living in Cayenne, Kourou, and Saint Laurent. Together with the Salvation Islands, Ilet la Mère forms part of this 'landscape of exclusion'. Boat trips to the island cost $€ 36$ per person and the only way of accessing the marina is via private car (Wayki Village, 2020).

The various periods during which Ilet la Mère operated as a site of sanctuary as well as confinement appeared to offer the possibility of sustainable cultivation for its small population. This possibility would endure for a decade or so before complete abandonment once more. The repetition of these possibilities emphasizes the island's exceptionality as a space within the colony and also suggests a pattern: a series of short-lived, failed projects. As suggested above, the island thus assumes a metonymic function for the wider colonial occupations. In contrast to other island imaginaries associated with the territory that evoke exile and containment, Ilet la Mère's repeated re-wilding maintains the fantasy of the frontier (Tsing, 2005). Located at the periphery of a peripheral space, the island and its multiple histories embody the idea of a fresh start, the persistence and triumph of nature, and the seemingly untapped potential for new human interventions.

\section{Conclusion}

As reporter Roubaud concludes in his account of his visit to Ilet la Mère in 1929, "It's a small island and a large demonstration" (Larique, 1929). While he was referring more specifically to the work carried out there by Edmond Duez and his wife, this observation seems to hold for the longer, ongoing colonial and postcolonial transformations of the island within the wider context of French Guiana. By focusing on these histories which frequently involve containment and confinement away from toxic activity on the mainland, this article has sought to demonstrate the role of the micro-island, Ilet la Mère, in the construction and persistence of a specific form of island ecology. Conceived in both material and imagined terms, this ecology deflects attention away from harmful social and ecological practices taking place elsewhere. The re-wilding of Ilet la Mère offers an image of a natural environment which effortlessly obscures and erases the ecological damage and genocide produced by colonial and neocolonial practices. At the same time, it functions as a 'landscape of exclusion', accessible only for tourist consumption. As such, it not only provides a distraction from other sites of exclusivity and exclusion, such as the Space Station and proposed open-pit gold mine, but actively contributes to the ongoing perpetuation of a colonial imaginary predicated upon such landscapes as inaccessible, exclusive, and awaiting contamination.

On disembarkation on Ilet la Mère, it is not long before the monkeys appear. There is something unnerving about their ubiquitous presence. Despite warnings from the tour operator, visitors continue to feed them snacks, including crisps and beer. The monkeys are extremely tame, posing for photos and jumping onto the backs and heads of those who feed them. Talking to different residents of French Guiana, people seem to be strongly divided as to whether this encounter with the monkeys is a magical experience or a traumatic ordeal 
never to be repeated. The monkeys are the last remaining survivors of the island's many failed and discontinued experiments. It is these experiments which ultimately define the site as one of exploitation and imprisonment, first of humans then of animals. The all-too-human behaviour of the squirrel monkeys cannot but call to mind, via a bizarre twist, the dehumanising, animal treatment of the enslaved persons and convicts who, after a life of suffering in plantations and forest camps, ended up on Ilet la Mère.

\section{Acknowledgments}

Field and archival work conducted for this article was generously funded by the British Academy (SG162446) and the Arts and Humanities Research Council (AH/R002452/1).

\section{References}

Administration Pénitentiaire. (1911-1924). [Individual dossier of Edmond Duez. Matricule 40056]. Archives Nationales d'Outre Mer (FR COL H1475.). Aix-en-Provence, France.

Agius, K., Theuma, N., Deidun, A., \& Camilleri, L. (2019). Small islands as ecotourism destinations: A central Mediterranean perspective. Island Studies Journal, 14(2), 115-136. https://doi.org/10.24043/isj. 97

Archer, L., \& Bawdon, F. (2010). Ricin! The inside story of the terror plot that never was. Pluto Press.

Audi, J., Belson, M., Patel, M., Schier, J., \& Osterloh, J. (2005, November 9). Ricin poisoning: A comprehensive review. Journal of the American Medical Association, 294(18), 2342-2351. https://doi.org/10.1001/jama.294.18.2342

Benoît, C. (2016). Etre de quelque part mais être né nulle part... Frontières et état civil en Guyane. In G. Collomb \& S. Mam-Lam-Fouck (Eds.), Mobilités, ethnicités, diversité Culturelle: La Guyane entre Surinam et Brésil (pp. 161-170). Ibis Rouge.

Bouyer, F. (1867). La Guyane Française: Notes et souvenirs d'un voyage éxecuté en 1862-1863. Hachette.

Calmot, A. (1979). Le Pénitencier de l'îlet la Mère (1852-1875). Revue Guyanaise d'histoire et de géographie, 11, 38-52.

Casey, J. (2021, January 6). Court orders French government to renew Orea's Montagne d'Or mining concessions. Global Mining Review. https://www.globalminingreview.com/finance-business/06012021/court-ordersfrench-government-to-renew-oreas-montagne-dor-mining-concessions/

Castor oil. (1857). Scientific American, 12(52), 411. https://www.jstor.org/stable/24951815

Ce pesticide interdit qui inquiète la Guyane. (2015, February 10). L'Humanité. https://www.humanite.fr/ce-pesticide-interdit-qui-inquiete-la-guyane-565084

Centers for Disease Control and Prevention. (2018). Facts about Ricin. https://emergency.cdc.gov/agent/ricin/facts.asp

Clarke, R., \& Johnston, A. (2016) Travelling the sequestered Isle: Tasmania as penitentiary, laboratory and sanctuary. Studies in Travel Writing, 20(1), 1-16. http://doi.org/10.1080/13645145.2015.1136091 
Conservatoire de l'espace littoral et des rivages lacustres. (2014). L'Ilet la Mère: Bienvenue sur un site préservé [Brochure]. http://www.ville-cayenne.fr/files/2014/01/Ilet-laMere.pdf

Cope, A. C., Dec, J., Cannan, R. K., Renshaw, B., \& Moore, S. (1946). Chemical warfare agents and related chemical problems-Volume I: Summary technical report of Division 9 (pp. 179-203). National Defense Research Committee. https://apps.dtic.mil/sti/pdfs/AD0234270.pdf

Cornuel, P. (2003). Guyane française: Du 'paradis' à l'enfer du bagne. In M. Ferro (Ed.), Le Livre noir du colonialisme. XIXe-XXIe siècle: de l'extermination à la repetentance (pp. 208219). Robert Laffont.

Curtis, S. A. (2008). Missionary utopias: Anne-Marie Javouhey and the colony at Mana, French Guiana, 1827-1848. In K. J. Callahan \& S. A. Curtis (Eds.), Views from the margins: Creating identities in modern France (pp. 21-52). University of Nebraska Press. https://doi.org/10.2307/j.ctt1dgn3mw.4

DeLoughrey, E. (2019). Allegories of the Anthropocene. Duke University Press.

Eastaugh, N. (2004). The pigment compendium: A dictionary of historical pigments. Elsevier Butterworth-Heinemann.

Faure, R. (1846). Typhus différent de la fièvre typhoide, observé dans les hopitaux du Bagne et de Saint-Mandrier de Toulon. Imprimerie du Veuve Baume.

Favre, A. (1865, April 12). [Tournée d'inspection sur les établissements pénitentiaires. Addressed to the Minister of the Colonies]. Archives Nationales d'Outre Mer (FR COL H24). Aix-en-Provence, France.

Forster, C. (1996). France and Botany Bay: The lure of a penal colony. Melbourne University Publishing.

Fougère, É. (2018). Les Îles Malades: Léproseries et lazarets de Nouvelle-Calédonie, Guyane et Guadeloupe. Classiques Garnier.

Godfroy, M. (2002). Bagnards. Éditions du Chêne.

Goix, S., Maurice, L., Laffont, L., Rinaldo, R., Lagane, C., Chmeleff, J., Menges, J., Heimbürger, L.-E., Maury-Brachet, R., \& Sonke, J. E. (2019). Quantifying the impacts of artisanal gold mining on a tropical river system using mercury isotopes. Chemosphere, 219, 684-694. https://doi.org/10.1016/j.chemosphere.2018.12.036

Grydehøj, A. (2018). Islands as legible geographies: Perceiving the islandness of Kalaallit Nunaat (Greenland). Journal of Marine and Island Cultures, 7(1). https://doi.org/10.21463/jmic.2018.07.1.01

Grydehøj, A., \& Kelman, I. (2017). The eco-island trap: Climate change mitigation and conspicuous sustainability. Area, 49(1), 106-113. https://doi.org/10.1111/area.12300

Harrison, R. (2020). Heritage as future-making practices. In R. Harrison, C. DeSilvey, C. Holtorf, S. Macdonald, N. Bartolini, E. Breithoff, H. Fredheim, A. Lyons, S. May, J. Morgan, \& S. Penrose (Eds.), Heritage futures: Comparative approaches to natural and cultural heritage practices (pp. 20-50). UCL Press. https://doi.org/10.2307/j.ctv13xps9m.8

Hellal, J., Schäfer, J., Regis, V., Lanceleur, L., \& Laperche, V. (2020). Impact of old and recent gold mining sites on mercury fluxes in suspended particulate matter, water and sediment in French Guiana. Applied Sciences, 10(21), 7829. http://doi.org/10.3390/app10217829 
Hennique, A. (1868, October). [Tournée d'inspection sur les établissements pénitentiaires. Addressed to the Minister of the Colonies]. Archives Nationales d'Outre Mer (FR COL H24). Aix-en-Provence, France.

Hennique, A. (1866, October 30). [Compte rendu de la tournée du Gouverneur sur les établissements pénitentiaires. Addressed to the Minister of the Colonies]. Archives Nationales d'Outre Mer (FR COL H24). Aix-en-Provence, France.

Institut Pasteur de la Guyane. (2015). 75 ans au service de la recherche et de l'appui à la santé publique en Guyane [Brochure]. https://www.pasteur-cayenne.fr/wpcontent/uploads/2015/12/IPG-DP-75-ans.pdf

Jantet, E., Bouteiller, P., Briswalter, M., \& Masson, J. (2012, May 10). L'agriculture en Guyane: En quête d'autonomie et de qualité. Une Saison en Guyane. https://www.unesaison-en-guyane.com/n07/lagriculture-en-guyane-en-quete-dautonomie-et-dequalite-2/

Larique, M. (1929, February 14). Notre grand referendum concours: IX - Duez. Détective, 16, p. 12. https://criminocorpus.org/fr/bibliotheque/page/91300/

Le Figaro \& AFP. (2020, December 3). Montagne d'or: Le refus de renouveler les concessions sur la sellette. Le Figaro. Retrieved April 4, 2021, from https://www.lefigaro.fr/flashactu/montagne-d-or-le-refus-de-renouveler-les-concessions-sur-la-sellette-20201203

Leong-Salobir, C. (2011). Food culture in colonial Asia: A taste of empire. Routledge.

LePoint.fr. (2017, March 27). Emanuel Macron et "l'île de Guyane". Le Point. https://www.lepoint.fr/presidentielle/emmanuel-macron-et-1-ile-de-guyane-27-032017-2115006 3121.php

Lowenthal, D. (1952). Colonial experiments in French Guiana, 1760-1800. The Hispanic American Historical Review, 32(1), 22-43. http://doi.org/10.2307/2508907

Mam-Lam-Fouck, S. (1982). La Guyane française du XVIIe siècle à 1960: De la colonisation à la départementalisation. Désormeaux.

Maurice, J. (n.d.) 'Camp de la Transportation' [Exhibition panel]. Musée du bagne et de la ville de Saint Laurent-du-Maroni.

"There is no ban on the use of cyanide for gold mining...". (2018, November 21). Mining Journal. $\quad$ https://www.mining-journal.com/gold-and-silvernews/news/1351488/"there-is-no-ban-on-the-use-of-cyanide-for-gold-mining"

Nixon, R. (2011). Slow violence and the environmentalism of the poor. Harvard University Press.

O'Brien, W. (2015). Landscapes of exclusion: State Parks and Jim Crow in the American South. University of Massachusetts Press.

Payraud, N. (2016). Cayenne (Guyane). Îlet La Mère. Archéologie médiévale, 46, 204-205. https://doi.org/10.4000/archeomed.7273

Pierre, M. (2017). Le temps des bagnes. 1748-1953. Tallandier.

Pierre, M. (2006). Le siècle des bagnes coloniaux (1852-1953). Criminocorpus. http://journals.openedition.org/criminocorpus/174

Pommeuse, M. L.-F. (1832). Des colonies agricoles et de leurs avantages pour assurer le secours a l'honnête indigence. Huzard.

Raver, A. (1994, September 11). The castor bean plant: So striking, so poisonous. The New York Times, S1, 62. https://www.nytimes.com/1994/09/11/nyregion/cuttings-thecastor-bean-plant-so-striking-so-poisonous.html 
Raza Kolb, A. F. (2020). Epidemic empire: Colonialism, contagion and terror, 1817-2020. University of Chicago Press.

Rousseau, L. (1930). Les hommes punis: Un médecin au bagne. Éditions Armand Fleury.

Sanchez, J.-L. (2019). Le bagne colonial de Guyane française (XIXe-XXe siècles): Les transportés au camp de la transportation de Saint-Laurent-du-Maroni. In J. D. Cesano, J. A. Núñez, \& L. González Alvo (Eds.), Historia de las prisiones sudamericanas. Entre experiencias e historia comparada (Siglos XIX y XX) (pp. 329-414). Humanitas.

Sanchez, J.-L. (2018). The French empire, 1542-1976. In C. Anderson (Ed.), A global history of convicts and penal colonies (pp. 123-155). Bloomsbury.

Spieler, M. F. (2012). Empire and underworld: Captivity in French Guiana. Harvard University Press.

Stansbery, G. (2011). Space waste. In T. M. Letcher \& D. A. Vallero (Eds.), Waste: A handbook for management (pp. 377-391). Academic Press.

Stoler, A. L. (2016). Duress: Imperial durabilities in our times. Duke University Press.

Sullivan, R. J. (1794). A view of nature, in letters to a traveller among the Alps with reflections on atheistical philosophy, now exemplified in France. T. Becket.

Tardy de Montravel, L.-M.-F. (1863a, October). [Tournée d'inspection sur les établissements pénitentiaires. Addressed to the Minister of the Colonies]. Archives Nationales d'Outre Mer (FR COL H24). Aix-en-Provence, France.

Tardy de Montravel, L.-M.-F. (1863b, December 15). [Tournée d'inspection sur les établissements pénitentiaires. Addressed to the Minister of the Colonies]. Archives Nationales d'Outre Mer (FR COL H24). Aix-en-Provence, France.

Temporal, F., Marie, C., \& Bernard, S. (2011). Insertion professionnelle des jeunes ultramarins: DOM ou métropole? Population (French edition), 66(3/4), 555-599. https://doi.org/10.3917/popu.1103.0555

Toth, S. (2006). Beyond Papillon: The French overseas penal colonies, 1854-1952. University of Nebraska Press.

Tripot, J. (1910). La Guyane. Au pays de l'or, des forçats et des peaux-rouges. Plon.

Tsing, A. L. (2005). Friction: An ethnography of global connection. Princeton University Press.

Wollentz, G., \& Högberg, A. (2020). Toxic heritage: Uncertain and unsafe. In R. Harrison, C. DeSilvey, C. Holtorf, S. Macdonald, N. Bartolini, E. Breithoff, H. Fredheim, A. Lyons, S. May, J. Morgan, \& S. Penrose (Eds.), Heritage futures: Comparative approaches to natural and cultural heritage practices (pp. 294-312). UCL Press. http://doi.org/10.2307/j.ctv13xps9m.25

Wood, S., \& MacLeod, C. (2018). Introduction. In S. Wood \& C. MacLeod (Eds.), Locating Guyane (pp. 1-14). Liverpool University Press.

Wayki Village. (2020). Nos prestations - Ilet la Mère. http://www.waykivillage.fr/nos prestations/ilet la mere.html\#journee 